\title{
“KONTRAK PERILAKU” DAPAT MENANAMKAN KEBIASAAN BAIK PADA SISWA KELOMPOK B3 TK MASYITHOH PIJENAN BANTUL SEHINGGA MENJ ADI SISWA YANG BERKARAKTER “ MANTAB”
}

\author{
Nanik Sunarni \\ TK Masyithoh Pijenan \\ e-mail: naniksunarni67@gmail.com
}

\begin{abstract}
Abstrak
Best Practice ini dilakukan untuk menanamkan karakter mandiri dan tanggung jawab dengan " Kontrak Perilaku " di TK Masyithoh Pijenan. Pengamatan dan penggunaan "Kontrak Perilaku” ini dilaksanakan dari tanggal $18 \mathrm{~J}$ uli sampai dengan 18 Agustus 2017. Siswa yang ada di kelompok B3 berjumlah 20 anak. Pengamatan diawali dari hari pertama masuk sekolah. Dalam Kurikulum2013 PAUD lingkup perkembangan Sosial Emosional anak berumur 5-6 seharusnya sudah memperlihatkan kemampuan diri untuk menyesuaikan diri, mengenal perasaan sendiri dan mampu mengelolanya secara wajar,tahu akan haknya, mentaati aturan kelas, mengatur diri sendiri, bertanggung jawab atasperilakunya untuk kebaikan diri sendiri,mengekspresikan emosi yang sesuai dengan kondisi yang ada,dan bersikap kooperatif. Tujuan pendidikan anak usia dini adalah terbentuknya generasi yang beriman, bertaqwa,cerdas, terampil, mandiri dan berbudaya. Hal tersebut belum muncul pada perilaku anak- anak kelompok B3 karena ditemukan dari pengamatan masih banyak siswa yang menangis saat ditinggal ibunya. Setelah selesai bermain, anak- anak tidak mengembalikan mainan pada tempatnya, lebih suka bermain danbercanda dari pada menyelesaikan dan melakukan apa yang menjadi tugas dan perintah guru. Hal ini yang membuat guru melakukan Kontrak Perilaku kepada anak anak kelompokB3 untuk menanamkan kemandirian dan rasa tanggungjawab. Setelah Kontrak Perilaku diterapkan pada anak- anak kelompok B3 TK Masyithoh PijenanBantul maka dapat disimpulkan bahwa Kontrak Perilaku ini sangat tepat untuk menanamkan karakter pada anak usia dini sehingga mereka saat ini sudah mandiri dan bertanggungjawab.
\end{abstract}

Kata Kunci: best practice, pendidikan anak usia dini, kontrak perilaku

\begin{abstract}
The Best Practice was done to train contract of independent behavior and responsibility by applying "Behavior Contract" to Masyitoh Pijenan kindergarten. The observation and application of "Behavior Contract" was done from $18 \mathrm{~J}$ uli 2017 until 18 August 2017. The B3 class consisted of twenty students. The observation was started on the first day of school. In curriculum 2013 of early childhood education, the scope of social emotional development, age 5-6 and so on, shows the students' ability to adapt, to recognize and manage their own feelings, to know their rights, to follow the class rules, to do self regulation and their responsibility of their actions, to express their emotions, and to be cooperative. The early childhood education aims at
\end{abstract}


shaping young generation to be faithful, devoted, smart, skilled, independent, and cultured. The characteristics above could not be seen in the students of B3 class' behavior since some of the students still cried when their mothers left them at school, did not tidy their toys up when they had done playing, preferred to play with their friends instead of working on the assignments given by the teacher. The students' behaviors above encouraged the teacher to apply Behavior Contract to the students of B3 class. Therefore, they could be more independent and responsible. Behavior Contract could be chosen as the perfect method to shape children characteristic. The students of B3 class in Masyitoh Pijenan who came to be more independent and responsible after the Behavior Contract was applied was the proof.

Keywords: best practice, early childhood education, behavior contract

\section{PENDAHULUAN}

Dalam Permendikbud 137 tentang Standar Nasional Pendidikan Anak Usia Dini Lampiran I, Standar Isi tentang Tingkat Pencapaian Perkembangan Anak pada kelompok usia 5- 6 tahun pada lingkup perkembanagan Sosial Emosional mengamanatkan bahwa setiap siswa yang berusia 5-6 tahunhendaknya telah memiliki : 1) Memperlihatkan kemampuan diri untuk menyesuaikan dengan situasi, 2) Memperlihatkan kehati- hatian kepada orang yang belum dikenal ( menumbuhkan kepercayaan pada orang dewasa yang tepat ). 3) Mengenal perasaan sendiri dan mengelolanya secara wajar, 4) Tahu akan haknya, 5)Mentaati aturan kelas, 6) Mengatur diri sendiri. Dari uraian di atas jelas terlihat bahwa setiap siswa TK yang berusia 5- 6 tahun hendaknya sudah dapat mandiri, mengendalikan emosi secara wajar dandapat mentaati aturan yang sudah ada. Kenyataan di lapangan yang penulis amati secara seksama dari tanggal 18 Juli sampai dengan 18 Agustus 2017, masih banyak siswa di kelompok B3 yang menangis sangat keras dan sangat sulit untuk bisa tenang dan masih banyak siswa yang kurang bisa bertanggung jawab pada apa yang telah dilakuaknnya.Hasil pengamatan menunjukkan para siswa kelompok B3 masih menangis saat ditinggal orang tuanya, anak- anak juga belum bisa mengembalikan mainannya setelah selesai digunakan. Di TK Masyithoh Pijenan memiliki visi membentuk generasi yang beriman bertaqwa kapada Tuhan Yang Maha Esa, cerdas , kreatif mandiri dan berbudaya, oleh karena itu kami menerapkan aturan secara bersama agar anak tidak ditunggui selama jam sekolah. Aturan tersebut sudah disepakati bersama anatara guru, orang tua murid dan siswa, akan tetapi dalam kenyataannya siswa kelompok B3 belum dapat mencapai Tingkat Pencapaian Perkembangan anak yang diamanatkan dalam Permendikbud No 137.

Kenyataan di lapangan tersebut sangat mengusik penulis untuk mencari cara ataupun strategi yang tepat agar anak-anak siswa kelompo B5 dapat mandiri dan bertanggung jawab. Upaya yang dilakukan kali ini adalah dengan membuat kontrak perilaku antara guru dan siswa dengan harapan mereka akan dapat merubah perilakunya menjadi lebih baik.Kontrak yang dibuat tersebut mengandung hukuman dan hadiah. Dengan pemberian perlakuan ini secara terus menerus diharapkan nantinya akan menjadi kebiasaan baik yang dilakukan siswa, sehingga akan melekat dalam diri 
siswa, membentuk karakter yang mandiri dan bertanggung jawab.

\section{Perumusan Masalah}

Berdasarkan latar belakang tersebut dapat di rumuskan permasalahan yang muncul adalah :

1. Apakah dengan kontrak perilaku yang dilakukan guru dan murid kelompok B3 ini dapat menanamkan kemandirian pada anak?

2. Apakah dengan kontrak perilaku ini dapat menanamkan rasa tanggung jawab pada anak?

\section{Manfaat dan Tujuan}

Manfaat yang dapat diperoleh guru adalah anak- anak akan lebih mandiri dan bertanggung jawab sehingga Tingkat Pencapaian Perkembangan Anak bisa tercapai. Tujuan dari penerapan kontrakperilaku ini adalah untuk menanamkan kemandirian anak dan untuk menanamkan rasa tanggung jawab pada anak.

\section{Kontrak Perilaku}

\section{Kontrak.}

Dalam Kamus Bahasa Indonesia yang dimaksud dengan kontrak adalah perjanjian ( secara tertulis ) antara dua pihak , dapat pula diartikan sebagai persetujuan yang bersangsi hukum antara dua fihak atau lebih untuk melakukan atau tidak melakukan kegiatan. Pada kesempatan ini kontrak yang dimaksud adalah persetujuan yang bersangsi / hukuman dan atau hadiah antara dua fihak untuk melakukan suatu aturan yaitu guru dan murid. Fihak yang melakukan kegiatan adalah murid sedangkan fihak yang menerima hukuman atau hadiah adalah guru. Hadiah yang akan diberikan kepada murid tentunya telah mendapatkan kesepakatan antara kedua belah fihak, demikian pula dengan hukumannya.
2. Perilaku.

Perilaku dapat diartikan sebagai tanggapan atau reaksi individu terhadap rangsangan atau lingkungan,yang dimaksud disini perilaku adalah ketaatan untuk melakukan sesuatu dikarenakan adanya perintah dari luar dalam hal iniadalah guru. Lebih jelasnya perilaku yang dimaksud disini adalah kegiatan yang dilakukan oleh murid atas perintah dari guru. Kontrak perilaku yang dimaksud adalah kesepakatan yang dibuat antara guru dan murid agar mau melakukan aturan, disiplin, ataupun perilaku- perilaku yang baik, dengan tujuan agar anak menjadi mandiri dan disiplin.

\section{Pengertian Karakter}

Karakter adalah kebagusan perilaku, rasa, dan pikiran yang dipahat. Sebagai kebagusan yang dipahat, mau tak mau, pendidikan karakter harus dilakukan secara intensif, sejak dini, dan menyeluruh.( Musfiroh, 2011: v ). Mustofa yang dikutip oleh Musfiroh mengatakan bahwa karakter merupakan pola perilaku seseorang, yang ditopang oleh pengetahuan dan rasa cinta terhadap kebajikan, dan kemampuan untuk merealisasikan kebajikan itu dalam perilaku sehari- hari. Karakter merupakan hasil terpadu dari kerja otak, hati, dan seluruh anggotabadan lainnya. Karakter adalah aksi nyata yang dipandu cahaya pengetahuan dan cinta kasih yang baik. ( 2011: vi )

Lebih lanjut dijelaskan bahwa karakter secara etimologi berarti memahat atau mengukir.Hal ini menunjukkan bahwa karakter tidak terbentuk secara instan, untuk mengukirnya membutuhkan waktu dan cara yang benar.Karakter juga merupakan gambaran perilaku yang bermuatan nilai ( benar- salah, baik- buruk ) baik secara eksplisit maupun implicit. Mirip dengan 
kepribadian, karakter bersifat permanen, meskipun demikian kepribadian terbebas dari nilai, sedangkan karakter justru menonjolkan nilai ( Alwisol yang dikutip oleh Musfiroh, 2011: vii )

\section{Hakikat Karakter}

Membangun karakter anak sejak dini, menjadi sangat penting di era global ini, baik oleh orang tua maupun guru. Harapannya adalah agar anak memiliki karakter yang baik . Pendidikan karakter dapat dilakukan baik di ligkungan keluarga maupun sekolah.Pendidikan karakter ini menjadi topic utama dalam dunia pendidikan karena dapat menjadi salah satu cara pembentukan akhlak mulia bagi generasi bangsa. Semua orang tua mendambakan anak- anaknya menjadi pribadi yang berperilaku baik, jujur, dan menjadi anak- anak yang unggul dan mampumenghadapi tantangantantangan yang akan dihadapinya dimasa yang akan datang. Untuk mewujudkannya sangat diperlukan lingkungan yang nyaman dan mendukung rangsangan- rangsangan positif sehingga mampu mengoptimalkan potensi- potensi yang dimiliki anak.Hal ini diharapkan mampu menjadi upaya nyata bagi terwujudnya generasi yang berkarakter Indonesia yang menjadi harapan dimasa yang akan datang.

Hasil Penelitian George Boggs yang dikutip oleh Diana menyatakan bahwa terdapat 13 indikator penentu keberhasilan seseorang dimasa depan, sepuluh diantaranya adalah sikap tangguh, yakni : 1) Jujur dan dapat diandalkan, 2) Bisa dipercaya dan tepat waktu, 3) Bisa menyesuaikan diri dengan orang lain, 4) Bisa bekerja sama dengan orang lain, 5) Bisa menerima tugas dan kewajiban, 6) Mempunyai motivasi kuat untuk terus belajar meningkatkan kualitas diri, 7) Berpikir bahwa dirinya berharga, 8) Bisa berkomunikasi dan mendengarkan secara efektif, 9) Bisa bekerja mandiri dengan supervise yang minimum, 10) Dapat menyelesaikan masalah pribadi dan profesinya. Karakter merupakan sebuah eksplorasi terhadap nilai- nilai universal, meliputi strategi- strategi praktis yang mengacu pada tujuan dasar kehidupan, yaitu: niat/ keinginan untukmencapai kedewsaan denganwatak dan kepribadian yang matang, dan cinta/ keinginan untuk memberikan sumbangan yang berarti bagi masyarakat yang luas.( 2011: 149 )

Lebih lanjut dijelaskan oleh Diana bahwa karakter mulia tidak secara otomatis dimiliki oleh setiap manusia begitu ia dilahirkan, tetapi memerlukanproses yang panjang melalui pengasuhandan pendidikan. Pendidikan karakter adalah usaha aktif untuk membentuk kebiasaanbaik, sehingga sifat anak sudah terukir sejak kecil. Karakter juga merupakan nilai- nilai perilaku manusia yang berhubungan denganTuhan Yang Mahasa, diri sendiri, sesama manusia,lingkungan, dan kebangsaan yang terwujud dalam pikiran, sikap, perasaan, perkataan, dan perbuatan, berdasarkan norma- norma agama, hokum, tata karma, budaya dan adat istiadat. Stimulasi pendidikan karakterini dapat dilakukan sejak dalam kandungan sampai ia menjadi dewasa. Pemberian pendidikandimasa ini akan sangat mempengaruhi karakter anak dimasa yang akan datang. ( 2011, 151- 152 ).

\section{Prinsip Pembangunan Karakter di Usia Dini}

Baik orang tua maupun guru dalam menanamkan perilaku dan kebiasaan baik kepada anak kita perlu memahami tahapan perkembangan anak sehingga baik orang tua maupun guru dalam 
menanamkannya dapat tepat dan mencapai hasil yang optimal.Prinsipprinsip yang harus diperhatikan dalam penanaman karakter pada usia dini adalah sebagai berikut :

1. Pendidikan karakter dilakukan dengan penuh kasih sayang dan kepedulian. Keteladanan dari orang tua dan seluruh orang dewasa yang ada disekitar anak di lingkungan rumah secara konsisten dapat merangsang, kemampuan berempati, kepedulian dengan orang lai, dan mengembangkan perilaku proporsional.

2.Dilaksanakan dalam situasi yang menyenangkan. Situasi yang menyenangkan membentuk keterikatan dan kepedulian satu sama lainnya. Dalam lingkungan belajardemikian tumbuh perasaan aman, perasaanmenjadi bagian dari suatu kelompok, serta pengalaman untuk terlibat. Hubungan antara orang tua yang saling menghormati, menghargai dan dapat bekerjasama dengan baik akan memudahkan dalam menanamkan nilai- nilai dasar karakter pada anak.

3. Menggunakan pengembangan mencakup dan tercermin pada kegiatan bermain, media belajar, alatbantu yang dapat digunakan orang tua dalam menanamkan pendidikan karakter pada anak. Nilai karakter menjadi “ Ruh" yang tertanam pada diri anak.

4.Kegiatan bermain bersama dan teladan dari orang tua yang dilakukan dengan bermakna dan menantang membuat anak merasa dihargai, dan membantu mereka untuk meraih keberhasilan. Kegiatan yang dibuat orang tua/ guru harus melihat keberagaman bakat, minat dan kebutuhan anak, sehingga dapat membantumencapai potensi terbaik anak. 5. Menyediakan kesempatankesempatan bagi anak untuk melakukan tindakan- tindakan moral. Anak adalah pembelajar yang konstruktif dimana pembelajaran yang paling efektif adalah dengan cara melakukan sendiri ( children learn best by doing ). Mengembangkan karakter yang baik memerlukan banyak kesempatan bagi anak untuk menerapkan nilai- nilai seperti kebaikan, rasa tanggung jawab dankeadilan dalam kegiatannya sehari- hari. Melalui pengalaman moral yang berulang- ulang, anak akan memiliki pemahaman, dan mempraktekan kebiasaan- kebiasaan tersebut sehingga membentuk perilaku yang berkarakter.

6.Menumbuhkan motivasi dalam diri anak untuk mengembangkan karakter yang baik. Mengembangkan motivasi diri harus dilakukan secara hati- hati agar terlepas dari kekerasan atau penekanan yang mengarah pada pembentukan motivasi dari luar diri anak. Orang tua/ guru bersama dengan anak mengembangkan pemahaman terhadap aturan, kesadaran mengenai bagaimana perilaku perilaku mereka mempengaruhi orang lain, bertindak penuh rasa tanggung jawab, membantu anak memperbaiki perilaku dari kesalahan mereka dan berusaha memecahkan masalah.

7. Melibatkan anggota keluarga lainnya seperti nenek, kakek serta orang dewasa lainnya sebagai komunitas pembelajaran moral. Seluruh keluarga terlibat dalam berbagai tanggung jawab untuk pendidikan karakter dan mencoba untuk tetap berpegeng pada nilai- nilai dasar yang menjadi panduan dalam pendidikan anak.

8.Menjaga konsistensi penerapan nilainilai karakter dalam semua aspek, sehingga penanaman karakter pada anak 
akan dapat terwujud secara lebih optimal. ( Diana, 2011: 153- 155)

Dari uraian tersebut dapat dipetik maknanya bahwa untuk menanamkan karakter pada anak perlu dadanya kerjasama anatara sekolah dan orang tua, konsistensi antar keduanya dan ilakukan secara terus menerus. Pembentukan karakter ini diperlukan tiga hal yang dilakukan secara terintegrasi yaitu anak mengerti baik dan buruk, anak mempunyai rasa cinta kepada kebajikan, dan anak mampu melakukan kebajikan, danterbiasa melakukannya. ( Diana, 2011: 157)

\section{Cara melakukan Kontrak Perilaku}

Untuk melakukan kontrak perilaku ini ada beberapa tahapan yang akan dilakukan oleh guru dan murid yakni :

a. Tahap awal.

1) Setelah anak- anak masuk di dalam kelas guru mengajak anak untuk bernyanyi agar suasana menjadi lebih gembira.

2) Guru kemudian menyebutkan tata tertib dalam kelas yang harus ditaati oleh semua murid agar mereka menjadi lebih pintar. Adapun tata tertib di kelompok B5 adalah :

a) Anak- anak masuk kelas Jam 7.30 wib

b) Anak- anak berangkat sendiri.

c) Anak- anak mengikuti pelajaran dengan tertib tanpa mengganggu temannya.

d) Anak- anak menyelesaikan tugas yang diberikan guru dengan rapi dan sampai selesai.

e) Anak- anak mengembalikan alat permainan, buku dan alat tulis pada tempatnya setelah selesai digunakan.

3) Guru melaksanakan kontrak perilaku dengan anak- anak.
Adapun kontrak perilaku tersebut adalah : jika anak- anak melakukan tata tertib tersebut maka akanmendapatkan "Stiker " dan atau "Pin "( anak- anak boleh memilih )

Setelah sampai dirumah anak- anak diminta untuk menceritakan apa dan bagaiman " Pin " atau " Stiker " itu didapatkan , dengan harapan orang tua dapat mendukung apa yang dilakukan guru sehingga anak- anak dapat lebih mandiri dan bertanggung jawab.

4) Guru mengamati perilaku anak selama kontrak perilaku itu berlangsung.

5) Guru mencatat hasil yang sudah dicapai oleh anak- anak.

6) Guru membuat laporan.

Pihak- Pihak yang Terlibat dalam Pembentukan Karakter Pada Anak.

Untuk mewujudkan keinginan dantujuan pembentukan karakter yang baik tentunya diperlukan kerjasama antara beberapa fihak diantaranya adalah:

1. Orang Tua

Orang tua adalah tempat pendidikan yang pertama dan utama, menurut Bronfenbrenner ( 2004 ) yang dikutip oleh Ritta Eka Izzaty menyatakan bahwa keluarga termasuk dalam mikrosistem sebagai lingkungan yang paling berpengaruh dalam perkembangan anak.Hal ini disebabkan karena ikatan emosi yang diberikan orang tua sehingga berperankepada anak dalam pembentukantingkah laku anak. Interaksiorang tua dan anak menyediakan model bagi anak dalam berinteraksi dengan teman- temannya. Dengan berbagai macam cara yang diungkapkan melalui aktivitas pengasuhan, orang tua memberikan kontribusi pada perkembangan anak yang berhubungan denganpertemanan anak dengan teman 
sebayanya. Beberapa riset menjelaskan adanya hubungan antara aktivitas pengasuhan dan penerimaan teman sebaya yaitu; anak yang diabaikan cenderung memiliki karakter yang menghindar. Anak yang demikian anak yang tidak mendapat pengukuhan yang kuat dari orang tuanya untuk berinteraksi. (2011 :82 ) Dari penjelasan tersebut sangat terlihat jelas bahwa orang tua memiliki pengaruh yang besar terhadap pembentukan karakter anak.

2.Institusi Pra sekolah / Pendidik.

Institusi pendidikan prasekolah merupakan tempat anak- anak belajar mengembangkan berbagai macam aspek perkembangan yang ada pada dirinya, yang salah satunya adalah aspek social. Pendidikan yang menstimulasiperkembangan karakter anak pada intinya berisi tentang kajian yang berkenan dengan norma dannilai yang bermuara pada pembentukan moral. Institusi prasekolah diharapkan tidak hanya menyediakan tempat bermain, tapi juga diharapkan dapat terjadi internalisasi nilai- nilai yang diterima anak melalui bermain di lingkungan institusi atau sekolah. Melalui kegiatan bermain anak belajar mengembangkan kemampuan untuk mengolah dari dan teman bermain dalam konteks interaksi social. Dalam proses pembelajaran di institusi prasekolah, yang harus dilakukan pendidik adalah memberikan lingkungan dan stimulasi yang cocok untuk memenuhi kebutuhan anak didik sesuai dengan karakteristik perkembangannya. Pada usia dini ini juga salah satu kemampuan penting yang perlu dibelajarkan kepada anak adalah bagaimana cara untuk memahami diri untuk memahami diri dengan suatu permasalahan dari sudut pandang orang lain. Peran institusi disini juga tidak sedikit karena dilingkungan institusi melalui pembelajaran yang dapat membentuk pemahaman perilaku yang dapat diterima oleh lingkungan sekolah.

3. Organisasi keagamaan.

Peran organisasi keagamaan dalam mentransmisikan nilai- nilai diprediksikan efektif. Sebagai pihak pengontrol, organisasi keagamaan dapat berperan aktif sebagai jembatan antara pihak orang tua, pendidik, dan masyarakat dalam pengembangan perilaku. Melalui agama nilai- nilai moral ditekankan untuk dijalani sebagai pedoman untuk dapat menyesuaikan diri dalam berbagai konteks.Di dalam organisasi keagamaan diharapkan juga melibatkan anak- anak. Hal ini dimaksudkan agar anakmengerti tentang arti penting nilai- nilai yang dianutnya bagi kehidupanmaupun lingkungan sosialnya.

4.Teman sebaya.

Dengan bermain bersama teman sebaya akan terjadi interaksi social, anak akan belajar berbagi, bergantian, mengendalikan dan menyelesaikan konflik, serta menjaga dan mempertahankan hubungan. Semakin anak banyak berinteraksi social, maka hubungan timbale balik akan terjadi sehingga secara psikologis kemampuan sosialisasi anak akan semakin terasah. Interaksi dengan teman sebaya adalah pusat sosialisasi pada masa kanak- kanak. Interaksi ini menambah kemahiran kompetensi social dan kompetensi yang bersifat komunikasi yang tidak seperti kontribusi yang diperoleh dari interaksi dengan orang dewasa.

5. Masyarakat.

Masyarakat dalam arti sempit yang dalam hal ini dapat dikatakan lingkungan yang melaksanakan pranata social bersama di dalam suatu lingkungan 
diharapkan saling mendukung mengembangkan karakter anak. Nilainilai moral yang seyogyanya dilakukan sejak isia awal menjadi satu focus penting dalam menciptakan program kegiatan masyarakat yang berbasis anak.

\section{HASIL DAN PEMBAHASAN Analisis Permasalahan}

Permasalahan yang muncul di Kelompok B3 adalah :

1. Masih banyak siswa yang datang terlambat kesekolah.

2. Masih banyak siswa yang menangis saat di tinggal orang tuanya

3. Masih banyak siswa yang tidak mengerjakan tugas yang disebabkan karena menangis ataupun memang karena kurang betanggung jawab.

4. Masih banyak siswa yang tidak mengembalikan alat- alat tulis ataupun mainan setelah selesai digunakan.

\section{Analisis Kontrak Perilaku Dengan Landasan Teori}

Kontrak perilaku yang sudah disepakati adalah :

Jika anak- anak melakukan tata tertib tersebut maka akanmendapatkan "Stiker " dan atau " Pin "( anak- anak boleh memilih )

Setelah sampai dirumah anakanak diminta untuk menceritakan apa dan bagaiman " Pin " atau " Stiker " itu didapatkan , dengan harapan orang tua dapat mendukung apa yang dilakukan guru sehingga anak- anak dapat lebih mandiri dan bertanggungjawab.

\section{Kesesuaian dengan Landasan Teori}

Karakter adalah kebagusan perilaku, rasa, dan pikiran yang dipahat. Sebagai kebagusan yang dipahat, mau tak mau, pendidikan karakter harus dilakukan secara intensif, sejak dini, dan menyeluruh.(Musfiroh,2011: v ).

Dari pengertian tersebut jelas bahwa kontrak perilaku yang dilakukan oleh guru adalah membiasakan berperilaku baik, mandiri, bertanggung jawab sejak anak sia dini, hal ini juga dilakukan secara intensif dan menyeluruh.

Hasil Penelitian George Boggs yang dikutip oleh Diana menyatakan bahwa terdapat 13 indikator penentu keberhasilan seseorang dimasa depan, sepuluh diantaranya adalah sikap tangguh, yakni : 1) Jujur dan dapat diandalkan, 2) Bisa dipercaya dan tepat waktu, 3) Bisa menyesuaikan diri dengan orang lain, 4) Bisa bekerja sama dengan orang lain, 5) Bisa menerima tugas dan kewajiban, 6) Mempunyai motivasi kuat untuk terus belajar meningkatkan kualitas diri, 7) Berpikir bahwa dirinya berharga, 8) Bisa berkomunikasi dan mendengarkan secara efektif, 9) Bisa bekerja mandiri dengan supervise yang minimum, 10) Dapat menyelesaikan masalah pribadi dan profesinya. Karakter merupakan sebuah eksplorasi terhadap nilai- nilai universal, meliputi strategistrategi praktis yang mengacu pada tujuan dasar kehidupan, yaitu: niat/ keinginan untukmencapai kedewsaan denganwatak dan kepribadian yang matang, dan cinta/ keinginan untuk memberikan sumbangan yang berarti bagi masyarakat yang luas.( 2011: 149 )

Dari ke- 13 indikator penentu keberhasilan pendidikan karakter kesemuanya sangat sesuai dengan kontrak perilaku yang telah dilakukan guru dengan murid, indicator jujur dan tepat waktu, dalam kontrak anak- anak diminta hadir tapat waktu bila ingin mendapatkan stiker, indicator dapat menyesuaikan diri, dalam kontrak dengan berangkat sekolah sendiri halini meneunjukkan 
menyesuaikan diri, indicator dapat menerima tugas kontrak yang telah dilakukan adalah anak yang menyelesaikan tugas dengan baik akan mendapatkan stiker, indicator motivasi yang kuat sesuai dengan kontrak perilaku karena dengan kontrak perilaku anak akan termotivasi untuk mengumpulkan stiker paling banyak. Indikator terus belajar juga sangat sesuai dengan kontrak perilaku karena anak yang tenang tidak tergantung dengan orang tua akan dapat belajar lebih tenang. Indikator selalu berfikir dirinya sangat berharga, dalam pembelajaran guru akan selalu memotivasi anak memberikan pujian tentang tugasnya, kemandiriannya maka dia akan bangga pada dirinya sendiri. Indikator dapat berkomunikasi secara efektif, dengan berangkat sendiri, apabila anak menemui kesulitan dia akan bertanya kepada guru hal ini memicu terjadinya komunikasi yang baik antara guru dengan murid. Indikator bekerja mandiri hal ini jelas sangat sesuaidengan kontrak yang dilakukan dengan berangkat sendiri anak akan berusaha untuk menyelesaikan tugas sendiri tanpa bantuan dari orang lain/ orang tua. Indikator terakhir yaitu mampu menyelesaikan masalah, dengan berangkat sendiri dia akan berusaha menyelesaikan masalahnya mungkin bersama temannya atau bertanya kepada gurunya. J adi kontrak perilaku yang dilakukan guru ini terdapat 13 indikator penentu keberhasialan pendidikan karakter sesuai dengan hasil penelitian yang telah dilakukan oleh George Boggs.

Prinsip- prinsip yang harus diperhatikan dalam penanaman karakter pada usia dini adalah sebagai berikut :
1. Pendidikan karakter dilakukan dengan penuh kasih sayang dan kepedulian. Keteladanan dari orang tua dan seluruh orang dewasa yang ada disekitar anak di lingkungan rumah secara konsisten dapat merangsang, kemampuan berempati, kepedulian dengan orang lai, dan mengembangkan perilaku proporsional.

2. Dilaksanakan dalam situasi yang menyenangkan. Situasi yang menyenangkan membentuk keterikatan dan kepedulian satu sama lainnya. Dalam lingkungan belajardemikian tumbuh perasaan aman, perasaanmenjadi bagian dari suatu kelompok, serta pengalaman untuk terlibat. Hubungan antara orang tua yang saling menghormati, menghargai dan dapat bekerjasama dengan baik akan memudahkan dalam menanamkan nilainilai dasar karakter pada anak.

3. Menggunakan pendekatan pengembangan, mencakup dan tercermin pada kegiatan bermain, media belajar, alatbantu yang dapat digunakan orang tua dalam menanamkan pendidikan karakter pada anak. Nilai karakter menjadi " Ruh" yang tertanam pada diri anak.

4. Kegiatan bermain bersama dan teladan dari orang tua yang dilakukan dengan bermakna dan menantang membuat anak merasa dihargai, dan membantu mereka untuk meraih keberhasilan. Kegiatan yang dibuat orang tua/ guru harus melihat keberagaman bakat, minat dan kebutuhan anak, sehingga dapat membantumencapai potensi terbaik anak.

5. Menyediakan kesempatankesempatan bagi anak untuk melakukan tindakan- tindakan moral. Anak adalah pembelajar yang konstruktif dimana pembelajaran yang paling efektif adalah dengan cara melakukan sendiri ( children learn best by doing ). Mengembangkan karakter yang baik memerlukan banyak 
kesempatan bagi anak untuk menerapkan nilai- nilai seperti kebaikan, rasa tanggung jawab dankeadilan dalam kegiatannya seharihari. Melalui pengalaman moral yang berulang- ulang, anak akan memiliki pemahaman, dan mempraktekan kebiasaan- kebiasaan tersebut sehingga membentuk perilaku yang berkarakter. 6. Menumbuhkan motivasi dalam diri anak untuk mengembangkan karakter yang baik. Mengembangkan motivasi diri harus dilakukan secara hati- hati agar terlepas dari kekerasan atau penekanan yang mengarah pada pembentukan motivasi dari luar diri anak. Orang tua/ guru bersama dengan anak mengembangkan pemahaman terhadap aturan, kesadaran mengenai bagaimana perilaku perilaku mereka mempengaruhi orang lain, bertindak penuh rasa tanggung jawab, membantu anak memperbaiki perilaku dari kesalahan mereka dan berusaha memecahkan masalah.

7. Melibatkan anggota keluarga lainnya seperti nenek, kakek serta orang dewasa lainnya sebagai komunitas pembelajaran moral. Seluruh keluarga terlibat dalam berbagai tanggung jawab untuk pendidikan karakter dan mencoba untuk tetap berpegeng pada nilai- nilai dasar yang menjadi panduan dalam pendidikan anak.

8. Menjaga konsistensi penerapan nilai- nilai karakter dalam semua aspek, sehingga penanaman karakter pada anak akan dapat terwujud secara lebih optimal. ( Diana, 2011: 153- 155)

Kontrak perilaku yang telah dilakukan guru tanpa paksaan tapi dengan hadiah hal itu menunjukkan rasa kasih sayang dari guru, juga merupakan hal yang menyenangkan, kegiatan kontrak perilaku ini dilakukan melalui pendekatan bermain, dan bermain bersama dalam kelompok. Dalamkegiatan yang dilakukan guru selalu member kesempatan kepada anak untuk melakukan hal- hal yang baik .Halini akan menumbuhkan motivasi bagi anak untuk selalu berbuat baik. Dalam pelaksanaan kontrak perilaku ini sangat dibutuhkan kerjasama dengan orang tua siswa dan selalu seiya sekata dengan mereka ( konsisten ).

Dengan demikian dari ke 8 prinsip pembangunan karakter pada anak usia dini ini ada dalam kontrak peilaku yang dilakukan guru.

a. Pihak- pihak yang terlibat dalam pembentukan karakter pada anak adalah : 1 ) orang tua, 2) Institusi pra sekolah/ pendidik, 3) Organisasi keagamaan, 4) Teman sebaya, 5) Masyarakat

Dari kelima pihak tersebut hanya organisasi keagamaan saja yang belum secara nyata memberikan kontribusi karena memang bagi anak- anak masih sangat sedikit kesempatan yang ada atau muncul dalam kegiatan organisasi keagamaan.

Data Empiris di Satuan Pendidikan Data empiris yang kami temukan di lapangan bisa saya tunjukkan pada data di bawah ini : 


\begin{tabular}{|l|l|l|l|l|}
\hline No & Indikator & Baik & Cukup & Kurang \\
\hline 1 & $\begin{array}{l}\text { Kemandirian } \\
\text { a. Tidak saat } \\
\text { ditunggui } \\
\text { sekolah. } \\
\text { b. Mengerjakan } \\
\text { tugas sendiri. } \\
\text { c. Mengambil } \\
\text { dan } \\
\text { mengembalikan } \\
\text { alat tulis sendiri } \\
\text { d. Menata loker } \\
\text { sendiri. }\end{array}$ & 2 & 18 \\
\hline 2 & $\begin{array}{l}\text { Tanggungjawab. } \\
\text { a. Menggunaka } \\
\text { n alat- alat sekolah } \\
\text { dengan tepat. } \\
\text { b. Menyelesaika } \\
\text { ntugas tepat waktu. } \\
\text { c. Mengembalik } \\
\text { an alat- alat } \\
\text { sekolah tanpa } \\
\text { disuruh. } \\
\text { d. Merawat } \\
\text { barang- barang } \\
\text { pribadi sendiri. }\end{array}$ & 3 & 17 \\
\hline
\end{tabular}

\section{PENUTUP}

\section{Kesimpulan}

Dari paparan diatas dapat disimpulkan bahwa :

1. Dengan kontrak perilaku anak menjadi lebih mandiri.

2. Dengan kontrak perilaku anak Saran menjadi lebih bertanggungjawab

1. Untuk guru.

Hendaknya selalu mencari strategi yang tepat agar pembelajaran lebih berhasil

2. Untuk wali murid.

Diharapkan selalu bekerja sama dengan sekolah, guru agar putraputrinya dapat berkembang lebih optimal.

\section{Rekomendasi}

Best Practices ini dapat dilanjutkan dalam bentuk penelitian tindakan kelas bagi guru kelas yang bersangkutan atau bagi penulis sendiri.

\section{DAFTAR PUSTAKA}

Hurlock, E.B ( 1999 ) Psikologi Perkembangan Suatu Pendekatan Sepanjang Rentang Kehidupan Manusia ( Terjemahan: Meitasari Tjandrasa). J akarta : Erlangga

Maria J. Wantah. (2005) Pengembangan Disiplin dan Pembentukan Moral Pada Anak Usia Dini.J akarta: Depdiknas.

Munif Chatib (2013) Kelasnya Manusia. Bandung: Kaifa.

Musfiroh Tadkiroatun dkk (2011) Karakter Sebagai Saripati Tumbuh Kembang Anak Usia Dini, Yogyakarta: Inti media.

Pedomaan Penyelenggaraan ForumIlmiah Guru (2015) J akarta: Kemendikbud.

Permendikbud no 146 ( 2014) Kurikulum 2013 Pendidikan Anak Usia Dini, J akarta: Depdikbud.

Pusat Bahasa Depdiknas (2007) Kamus Bahasa Indonesia, Jakarta: Balai Pustaka. 